Приведены результаты исследования особенностей семенной продуктивности растений D. peltata в естественных условиях г. Киева. Исследована биология цветения растений D. peltata на территории коллекционного участка Ботанического сада НУБиП Украины. Осуществлена оценка потенциальной и фактической семенной продуктивности, определен коэффициент семенной продуктивности, предоставлено морфологическое описание семян, определены его масса и размеры.

Полученные нами результаты исследований свидетельствуют о возможности семенного размножения и успешного выращивания растений-интродуцентов D. peltata в природно-климатических условиях Киева. Это будет способствовать увеличению ассортимента декоративно-лиственных и красиво цветущих растений для формирования системы зеленых насаждений города Киева.

Ключевые слова: Darmera peltata, цветок, плод, семена, потенциальная семенная продуктивность, фактическая семенная продуктивность.

Shvets Iryna, Kolesnichenko Elena. Seed Productivity of Plants Darmera peltata (Torr. ex Benth.) Voss (Saxifragaceae) in Conditions of Kiev. In conditions of introduction of Kyiv one of the important indicator which characterizing the biological properties of plants Darmera peltata (Torr. Ex Benth.) Voss and their level of adaptation to the new environment habitat is seed production. The learning of this issue is relevant for the development of scientific bases of generative reproduction.

The results of research the features of seed productivity the plants D. peltata in natural conditions of Kyiv is given. Studied the biology of flowering plants of $D$. peltata on the collection plot of Botanical Garden NULES of Ukraine. Results of estimation of potential and real seed productivity are resulted, defined coefficient of seed production, results of study the morphological description of seeds, their mass and size also is given.

Our results of research show the possibility of seed breeding and successful cultivation plants of D. peltata in climatic conditions in Kyiv. It will increase the range of decorative hardwood and beautifully-flowering plants to create a system of green spaces in Kyiv.

Key words: Darmera peltata, flower, fruit, seeds, potential seed productivity, real seed productivity.

Стаття надійшла до редколегії 06.03.2016 p.

УДК 712.253:581(477)

Анастасія Власенко

\title{
Оцінка декоративності дендросозоекзотів еx situ Степу України
}

У статті проаналізовано сучасні методики оцінки декоративності деревних рослин, на основі чого розроблено оригінальну шкалу комплексної оцінки, яку апробовано на 30 видах дендросозоекзотів ех situ, що охороняються на територіях природно-заповідного фонду Степу України.

Ключові слова: оцінка декоративності, дендросозоекзоти, ex situ, Степ України.

Постановка наукової проблеми та її значення. Нині існують різноманітні методики та шкали оцінки декоративності дерев і чагарників. Здебільшого вони грунтуються на якісних показниках сезонного розвитку рослин у цілому та окремих його стадій. Під час оцінки декоративності дендросозоекзотів ex situ штучних заповідних парків Степу України ми зіткнулися з труднощами застосування деяких загальноприйнятих методик і шкал комплексної оцінки декоративності деревних рослин [17; 16; 36]. Через значну кількість досліджених видів [5] дендросозоекзотів виникла потреба окреслити вибірку найраритетніших видів рослин. Відібрані види часто ростуть на територіях різних ботанічних садів, що ускладнює сезонну оцінку декоративних ознак рослин через значну віддаленість між ними. Особливості природних умов штучних заповідних парків зумовлюють набування рослинами одного й того самого виду відмінних зовнішніх декоративних ознак. Також більшість запропонованих шкал комплексної оцінки декоративності деревних рослин тією чи іншою мірою варто використовувати для оцінки ознак рослин певної біоморфологічної групи. Екзотична дендросозофлора ex situ штучних заповідних парків Степу України включає види чотирьох типів життєвих і сезонних форм деревних рослин: листяних та хвойних, листопадних і зимовозелених [6], що, безперечно, ускладнює оцінку декоративності для всіх видів дендроекзосозофлори дослідженого регіону за однією методикою.

(C) Власенко А., 2016 
Аналіз досліджень цієї проблеми. Серед методик оцінки декоративності однією з перших була робота Г. С. Мисника [21], у якій запропоновано шкалу для оцінювання декоративності рослин на стадії квітування. В. М. Билов [4] наводить методику порівняльної сортооцінки декоративних рослин, Л. І. Аткіна [1] пропонує комплексну оцінку сезонної декоративності насаджень, М. В. Ханіна та О. І. Довгалюк [35] розробили шкалу оцінки декоративності дерев і чагарників для зимового періоду. Г. О. Миронова та О. П. Чекалін [20] наводять методику естетичної оцінки хвойних паркових культурфітоценозів, Г. А. Паніна й В. Ф. Абаімов [26] запропонували методику на основі переліку декоративних ознак деревних рослин, запропонованого О. І. Колесніковим [11], В. М. Остапко та Н. Ю. Кунець [25] присвятили свою методику спеціально петрофітним видам природної флори. Шкали комплексної оцінки декоративності дерев і чагарників пропонували О. С. Заливська та М. О. Бабіч [3; 8], а також Н. А. Коляда [14], котра розробила й методику оцінки декоративності видів роду Fabaceae Juss. у фазі квітування [12]. Аналогічно Я. А. Крекова, А. В. Данчева, С. В. Залєсов [18] запропонували шкалу для видів роду Picea Dieter, Т. Р. Ланшакова [19] й Н. О. Рязанова [28] - для видів роду Acer L. В. Ю. Жиленко [7] розробила інтегральну шкалу оцінки декоративності представників роду Berberis L., Р. Г. Абдулліна та Н. О. Рязанова [1] - видів роду Sorbus L., Ф. К. Мурзамбулатова [22] - для видів роду Hydrangea L., Н. В. Полякова [27] - для видів роду Syringa L., а В. К. Зикова [9] (методика комплексної сортооцінки) - для Syringa vulgaris L., I. О. Сидоренко [29; 30] для рослин роду Rhododendron L., Р. А. Насурдінова [23] - для рослин роду Clematis L., С. I. Слюсар i C. I. Кузнецов [32; 33; 34] - для рослин родини Taxodiaceae F. W. Neger. Однак найчастіше для оцінки декоративності деревних рослин використовують комплексну методику Н. В. Котелової й О. М. Виноградової [17; 16], О. Г. Хороших та О. В. Хороших [36], а також 5-бальну шкалу О. А. Калініченка [10].

Мета дослідження - розроблення шкали комплексної оцінки декоративності раритетних видів деревних екзотичних рослин за основними морфологічними ознаками, іiї оптимізація для листяних та хвойних зимозелених, а також для листопадних дерев і чагарників.

Матеріали й методи дослідження. Розроблена інтегральна шкала включає елементи шкал О. Г. Хороших та О. В. Хороших [36], Н. А. Рязанової й В. П. Путєхіна [28], Н. А. Коляди [12; 14; 15], Я. А. Крекової, А. В. Данчевої та С. В. Залєсового [18], а також І. О. Сидоренко [29; 30].

Виклад основного матеріалу й обгрунтування отриманих результатів дослідження. Оцінку декоративних ознак деревних рослин пропонуємо здійснювати за чотирма основними блоками. Перший - це оцінка загальної декоративності рослини, яка включає період декоративності, декоративні ознаки крони (форма, щільність, фактура) і тривалість квітування та облистнення. Другий блок - це оцінка декоративності кірки, її фактури та забарвлення. Третій - це оцінка декоративності листків або хвої за формою, розмірами, забарвленням і сезонністю його змін. Четвертий блок - це оцінка декоративності генеративних органів рослини, яка грунтується на розмірах, забарвленні, рясності квіток (мегастробілів, суцвіть), а також формі, величині, забарвленні та рясності плодів або шишок у хвойних. У шкалу свідомо не включено показники зимостійкості, морозостійкості, посухостійкості й жаростійкості рослини, адже це внутрішня екотипічна здатність рослин протистояти комплексу несприятливих впливів зовнішнього середовища.

Загальна декоративність рослини. Час декоративності - це проміжок часу, протягом якого рослина не втрачає декоративності [17; 25]. Відповідно до рекомендацій Н. А. Рязанової [28] та Я. А. Крекової, А. В. Данчевої й С. В. Залєсового [18] виділено такі періоди: декоративність протягом усього календарного року (зимозелені рослини), вегетаційного сезону та певного періоду вегетації (уключає переважно декоративно-листяні, квітуючі й плодово-декоративні рослини). Декоративність крони. Форма крони - одна з найважливіших декоративних ознак деревних рослин [11]. Відповідно, уведено рекомендації щодо оцінки декоративності форми крони чагарників [30; 29; 7] та деяких хвойних рослин [33;34; 18]. Тривалість квітування - це проміжок часу (у днях) від розкриття першої квітки (початок квітування), до опадання, засихання останньої квітки (кінець квітування) [7; 31]. Тривалість облистнення - це проміжок часу, протягом якого листки залишаються на рослині.

У декоративних насадженнях вагоме значення мають щільність і фактура крони, адже краще сприймаються рослини зі щільною або ажурною фактурою крони, сформованою великими листками $[11 ; 14]$. Щільність крони має особливе значення в міських насадженнях, оскільки деревні рослини зі щільною кроною дають змогу чітко обмежити простір і створити фон для споруд та скульптур. Крім того, вони краще захищають від пилу, вітру й створюють тінь. Зі свого боку, деревні рослини з ажурною кроною збільшують виблиски світла та гру тіні й доповнюють ландшафтну фітокомпозицію [11]. 
Оцінка декоративності кірки. Фактура та забарвлення кірки деревної рослини мають виняткове значення в осінньо-зимовий період. Безперечно, найдекоративніше в цей період виглядають стовбури яскравого забарвлення або різнокольорові з гладкою чи глибокотріщинуватою фактурою кірки $[1 ; 18,19 ; 36 ; 11]$.

Оцінка декоративності листків або хвої. Декоративність листків (хвої) оцінюють за розмірами, формою, забарвленням і сезонністю його змін. Градацію за розмірами листкової пластинки та хвої наведено за роботою О. І. Колесникова [11]; градацію за формою листків - за працею Н. А. Коляди [14]. Також нами уведено характеристики для хвойних видів, де найвищий бал декоративності отримують зелені пагони рослин кипарисовиків, туй тощо. Для оцінки літнього забарвлення листків об’єднано пропозиції Н. А. Рязанової [28] для листяних та Я. А. Крекової [18] - для хвойних рослин.

Оцінка декоративності генеративних органів рослин. Із генеративних органів рослин оцінювали квітки покритонасінних, мікро- та мегастробіли голонасінних. Декоративність квіток (мікро-, мегастробілів), суцвіть. Для оцінки декоративності рослин під час квітування листяних і пилування хвойних виокремлено показники розмірів квіток (мегастробілів), суцвіть, забарвлення й рясність. Для генералізації оцінки вирішено об'єднати характеристики розмірів квіток та суцвіть. За наявності суцвіть дрібні квітки разом мають більш консолідований декоративний ефект, ніж кожна окремо. Натомість квітки великих розмірів справляють краще враження, коли вони поодинокі. Проте навіть невеликі або дрібні квітки можуть надавати рослині значної декоративності за рахунок яскравого забарвлення, рясності й терміну квітування. Тому в понятті декоративності працює принцип взаємозамінності ознак.

Декоративність плодів чи шишок. Найбільший емоційний ефект на людину справляють яскраво забарвлені великі плоди, лопатеві або такі, що мають різні вирости оплодня. Водночас сухі, побурілі та розтріскані плоди деяких рослин узимку та рано навесні можуть значно знижувати загальну декоративність рослини. Детальну шкалу оцінки декоративних ознак наведено в табл. 1.

Таблиия 1

Шкала ознак оцінки декоративності деревних рослин

\begin{tabular}{|c|c|c|c|}
\hline \multicolumn{2}{|c|}{ Генералізована ознака } & $\begin{array}{c}\text { Бал } \\
\text { оцінки }\end{array}$ & Детальна ознака \\
\hline \multicolumn{2}{|c|}{1} & 2 & 3 \\
\hline \multicolumn{4}{|r|}{ Загальна декоративність рослини } \\
\hline \multirow{3}{*}{\multicolumn{2}{|c|}{ Час декоративності }} & 5 & Протягом усього календарного року \\
\hline & & 3 & Протягом вегетаційного сезону \\
\hline & & 1 & Протягом окремого періоду вегетації \\
\hline \multirow{9}{*}{ Крона } & \multirow{3}{*}{ Форма } & 5 & $\begin{array}{l}\text { Рослини вирізняються чітко окресленою формою крони, } \\
\text { оригінальністю їі будови, стовбур прямий / кущ щільний із міцною } \\
\text { конструкцією та оригінальним каркасом крони }\end{array}$ \\
\hline & & 3 & $\begin{array}{l}\text { Парасолькова, овальна, «плакуча», сланка, спадаюча, подушкоподібна, } \\
\text { стовбур прямий або з незначним викривленням / кущ розріджений із } \\
\text { невиразним каркасом }\end{array}$ \\
\hline & & 1 & $\begin{array}{l}\text { Асиметрична округла, розкидиста, приземкувата, витка, стовбур } \\
\text { кривий / кущ пухкий, невиразної форми }\end{array}$ \\
\hline & \multirow{3}{*}{ Щільність } & 5 & Висока, однорідна, облистненість (охвоєність) до 82-100 \% \\
\hline & & 3 & Середня, облистненість (охвоєність) 51-81\% \\
\hline & & 1 & Ажурна, неоднорідна, облистненість (охвоєність) 21-50 \% \\
\hline & \multirow{3}{*}{ Фактура } & 5 & Велична ажурна або щільна з дуже великими листками \\
\hline & & 3 & Фонова ажурна з листками (хвоєю) довжиною 5-20 см \\
\hline & & 1 & Просвітна ажурна з дрібними листками (хвоєю) \\
\hline \multirow{5}{*}{ Тривалість } & \multirow{4}{*}{$\begin{array}{c}\text { Квітування } \\
\text { (пилування) }\end{array}$} & 5 & Значне (більше 24 діб) \\
\hline & & 3 & Середнє (10-24 діб) \\
\hline & & 1 & Короткочасне (до 10 діб) \\
\hline & & 0 & Рослина не квітує або й не пилує \\
\hline & Облистнення & 5 & $\begin{array}{l}\text { Рослина зимозелена / листки розвиваються рано навесні (квітень - } \\
\text { перша половина травня) та пізно восени опадають (друга половина } \\
\text { жовтня - листопад) }\end{array}$ \\
\hline
\end{tabular}




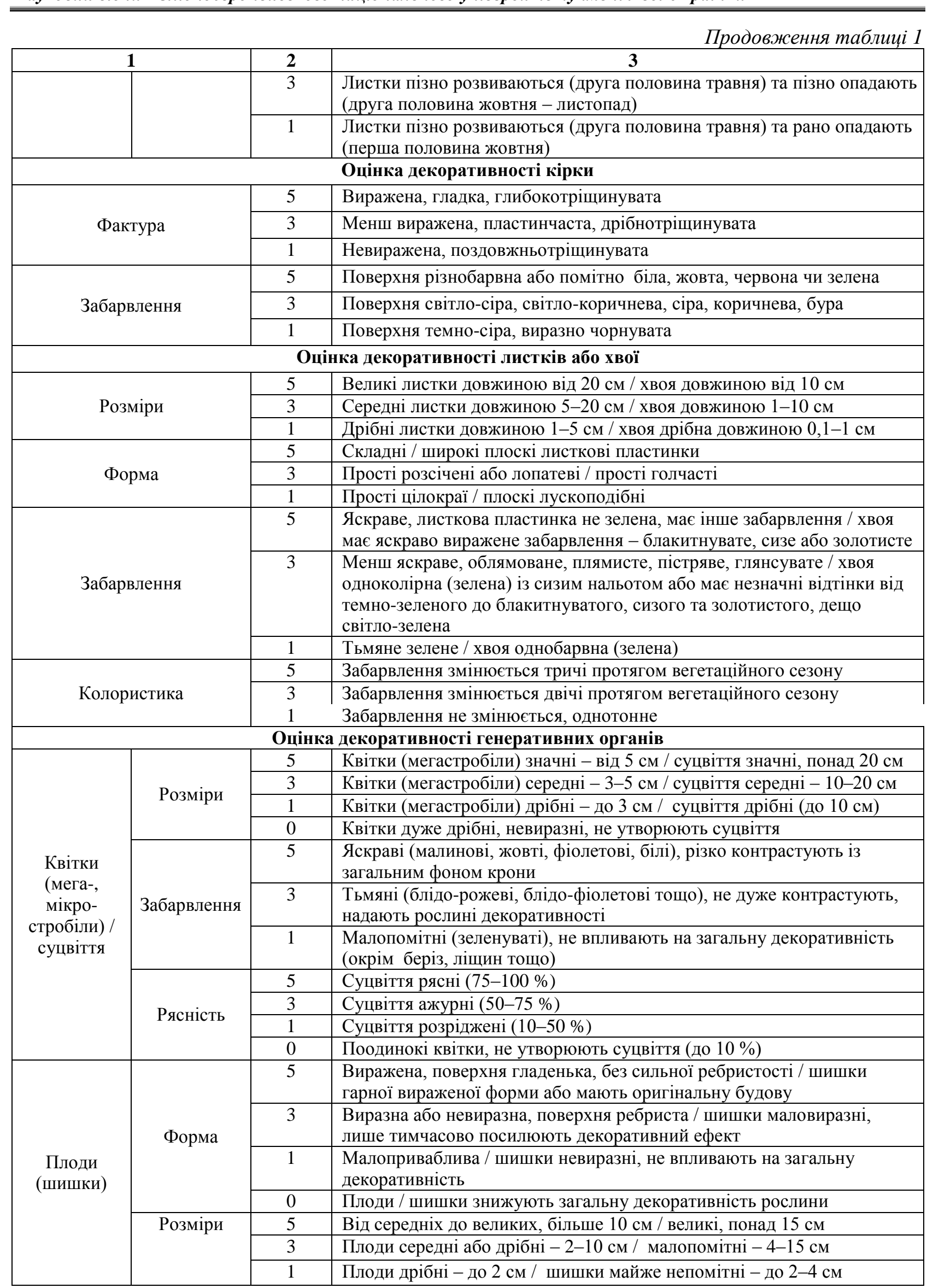


РОЗДІЛ І. Ботаніка. 7, 2016

Закінчення таблиці 1

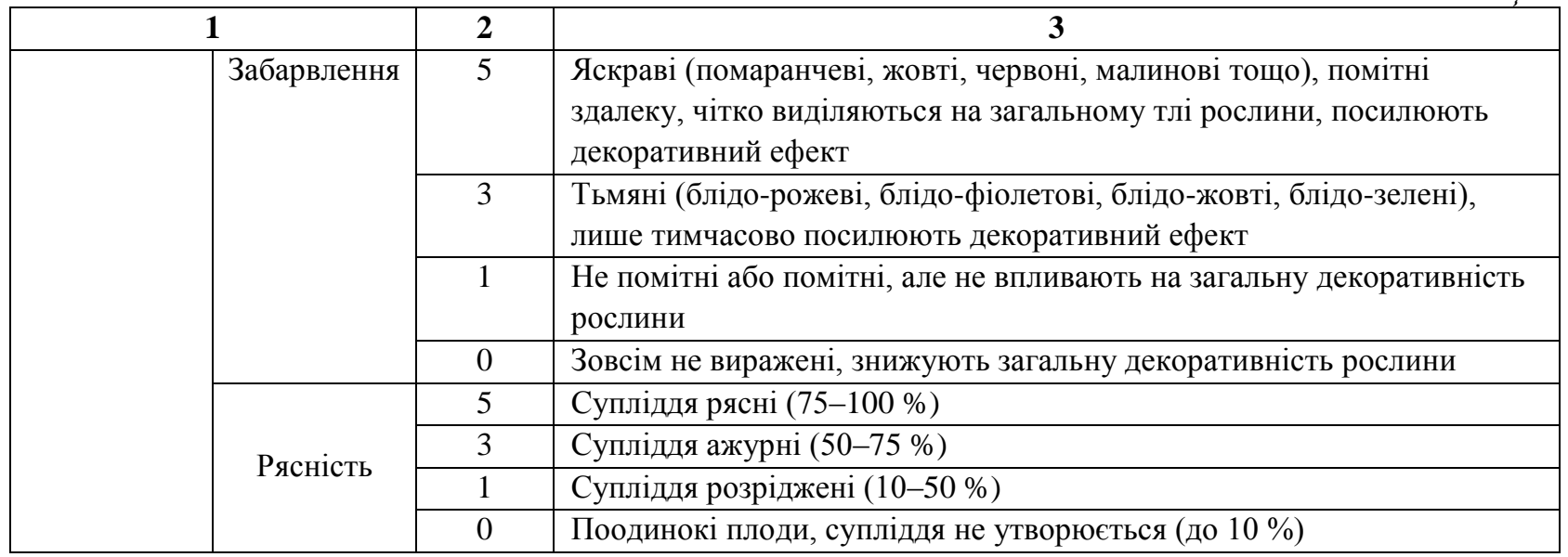

Для ознак, які погіршують загальний декоративний вигляд рослини (або їм неможливо надати вищу оцінку через відсутність указаної ознаки), уведено оцінку нуль балів. Амплітуда оцінки декоративності коливається від 13 до 90 балів. Загальну градацію ступенів декоративності рослини наведено в табл. 2.

Таблиия 2

Ступені оцінки декоративності дерев та чагарників

\begin{tabular}{|c|c|c|c|c|}
\hline \multirow{2}{*}{$\begin{array}{c}\text { Ступінь } \\
\text { декоративності, } \\
\text { балів }\end{array}$} & 13-40 & 41-50 & $51-64$ & 65-90 \\
\hline & $\begin{array}{c}\text { декоративність } \\
\text { низька }\end{array}$ & $\begin{array}{c}\text { декоративність } \\
\text { посередня }\end{array}$ & $\begin{array}{c}\text { декоративність } \\
\text { висока }\end{array}$ & $\begin{array}{c}\text { декоративність } \\
\text { дуже висока }\end{array}$ \\
\hline $\begin{array}{c}\text { Група } \\
\text { декоративності }\end{array}$ & IV & III & II & I \\
\hline
\end{tabular}

Описану вище методику апробовано для оцінки декоративності дендросозоекзотів ex situ Степу України. Із всього складу заповідної дендроекзосозофлори цього регіону довільно відібрано по 15 видів Magnoliophyta i Pinophyta piзних біоморф. До найдекоративніших (І група декоративності) віднесено три види - це Malus niedzwetzkyana Dieck ex Koehne, Cercis chinensis Bunge та Liquidambar styraciflua L., до II групи декоративності увійшли 23 види, III - чотири (табл. 3).

Таблиця 3

Сумарна кількісна оцінка декоративності видів заповідних дендросозоекзотів $e x$ situ Степу України

\begin{tabular}{|c|c|c|c|c|c|c|c|c|c|c|c|c|c|c|c|c|c|c|c|c|c|}
\hline \multirow{3}{*}{ 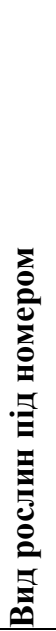 } & \multicolumn{6}{|c|}{$\begin{array}{c}\text { Загальна декоративність } \\
\text { рослини }\end{array}$} & \multicolumn{2}{|c|}{$\begin{array}{l}\text { Оцінка } \\
\text { декора- } \\
\text { тивності } \\
\text { кірки }\end{array}$} & \multicolumn{4}{|c|}{$\begin{array}{c}\text { Оцінка } \\
\text { декоративності } \\
\text { листків } \\
\text { або хвої }\end{array}$} & \multicolumn{7}{|c|}{$\begin{array}{l}\text { Оцінка декоративності } \\
\text { генеративних органів }\end{array}$} & \multirow{3}{*}{\multicolumn{2}{|c|}{ 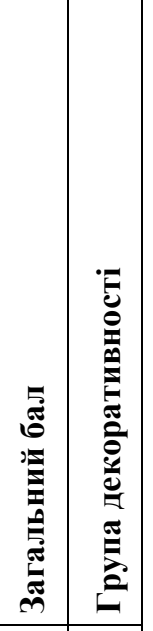 }} \\
\hline & \multicolumn{4}{|c|}{ крона } & \multicolumn{2}{|c|}{$\begin{array}{l}\text { трива- } \\
\text { лість }\end{array}$} & \multirow[b]{2}{*}{ 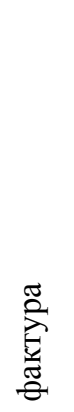 } & \multirow[b]{2}{*}{ 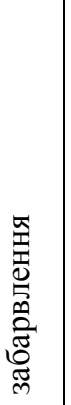 } & \multirow[b]{2}{*}{ 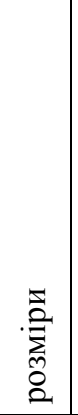 } & \multirow[b]{2}{*}{ 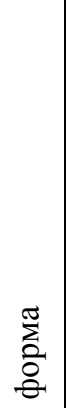 } & \multirow[b]{2}{*}{ 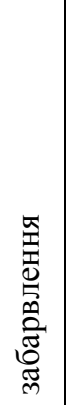 } & \multirow{2}{*}{ 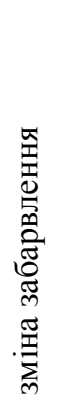 } & \multicolumn{3}{|c|}{$\begin{array}{c}\text { квітки } \\
\text { (мегастробіли) / } \\
\text { суцвіття }\end{array}$} & \multicolumn{4}{|c|}{ плоди (шишки) } & & \\
\hline & 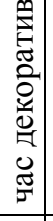 & 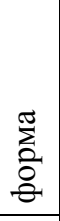 & 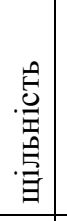 & 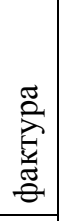 & 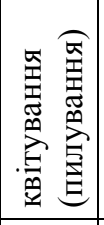 & 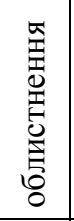 & & & & & & & 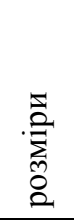 & 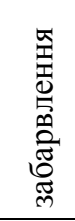 & 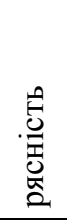 & 站 & 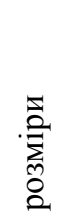 & 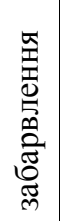 & 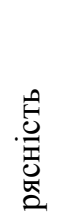 & & \\
\hline 1 & 2 & 3 & 4 & 5 & 6 & 7 & 8 & 9 & 10 & 11 & 12 & 13 & 14 & 15 & 16 & 17 & 18 & 19 & 20 & 21 & 22 \\
\hline 1 & 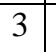 & 3 & 5 & 3 & 3 & 5 & 3 & 3 & 3 & 1 & 3 & 5 & 1 & 5 & 5 & 5 & 3 & 5 & 5 & 69 & \\
\hline
\end{tabular}




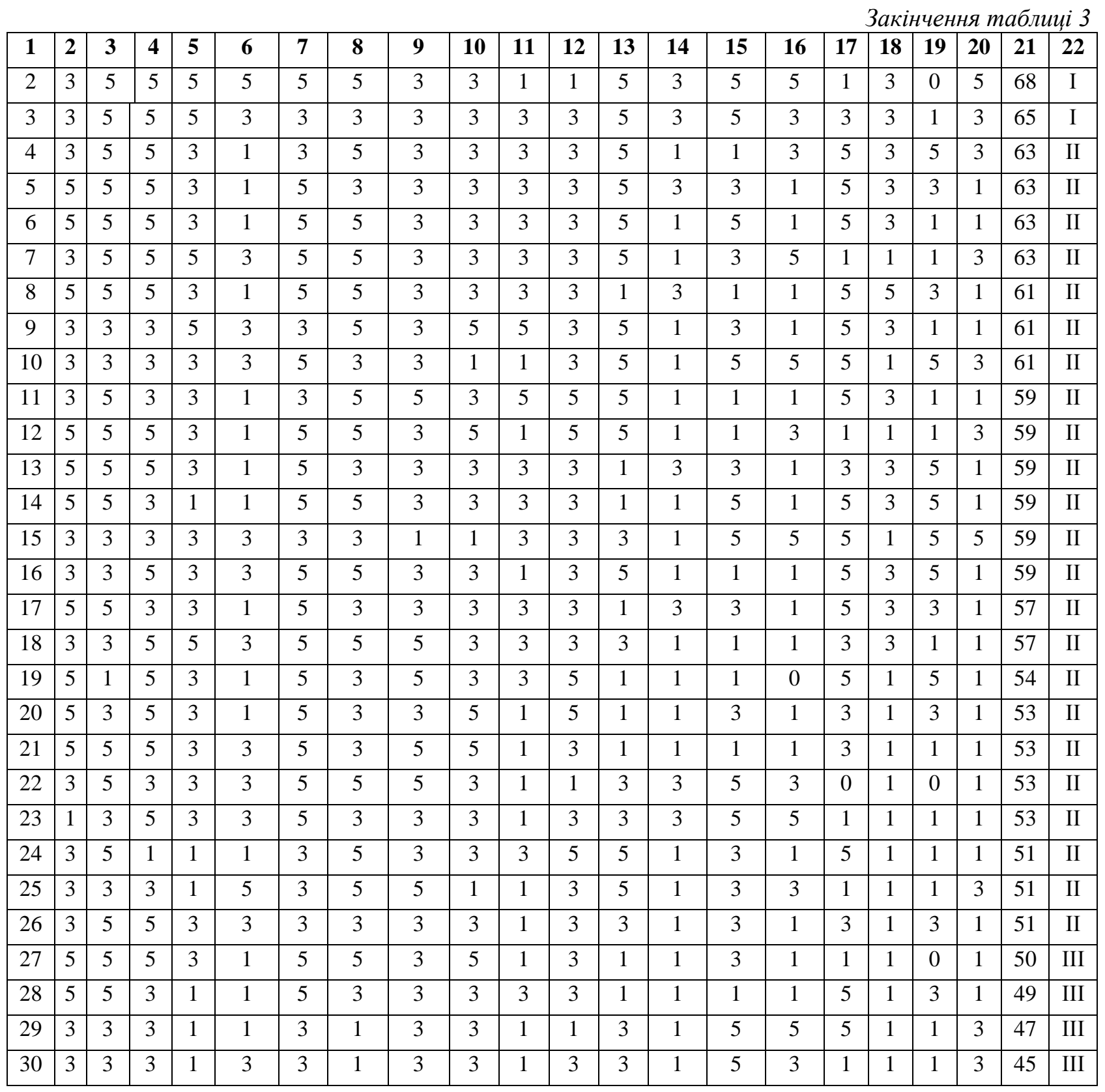

Примітка до табл. 3. 1 - Malus niedzwetzkyana Dieck ex Koehne; 2 - Cercis chinensis Bunge; 3 - Liquidambar styraciflua L.; 4 - Ginkgo biloba L.; 5 - Abies koreana Wils.; 6 - Pseudotsuga menziesii (Mird.) Franco; 7 - Acer divergens K. Koch et Pax; 8 - Abies numidica de Lannoy ex Carrière; 9 - Juglans regia L.; 10 - Berberis karkaralensis Kornilova et Potapov; 11 - Metasequoia glyptostroboides Hu et Cheng; 12 - Cupressus guadalupensis S. Watson; 13 - Picea asperata Mast.; 14 - Pinus heldreichii H. Christ.; 15 - Crataegus azarolus L.; 16 - Celtis caucasica Willd.; 17 Cedrus atlantica (Endl.) Manetti ex Carrière; 18 - Platanus orientalis L.; 19 - Taxus cuspidata Siebold \& Zucc.; 20 Juniperus horizontalis Moench.; 21 - Thuja plicata Donn ex D. Don; 22 - Sibiraea altaiensis Schneider; 23 Forsythia europaea Degen et Bald.; 24 - Larix kaempferi (Lamb.) Carrière; 25 - Betula raddeana Trautv.; 26 Quercus imbricaria Michx.; 27 - Chamaecyparis nootkatensis (D. Don) Spach; 28 - Tsuga canadensis (L.) Carrière; 29-Amygdalus ledebouriana Schlecht.; 30 - Abelia corymbosa Rgl. et Schmalh.

Висновки та перспективи подальшого дослідження. На основі власних результатів досліджень та літературних даних із застосуванням інтегровано-аналітичного підходу розроблена якісно нова шкала комплексної оцінки декоративності власне для раритетних видів екзотичних деревних рослин України. У результаті найвищі бали оцінки декоративності отримали Malus niedzwetzkyana Dieck ex Koehne (69), Cercis chinensis Bunge (68) та Liquidambar styraciflua L. (65). До групи високо- 
декоративних потрапили 23 види (Ginkgo biloba L., Abies numidica de Lannoy ex Carrière, Picea asperata Mast., Abies koreana Wils. та ін.), чотири види мають посередню декоративність (Chamaecyparis nootkatensis (D. Don) Spach, Tsuga canadensis (L.) Carrière, Amygdalus ledebouriana Schlecht., Abelia corymbosa Rgl. et Schmalh.). Дендросозоекзотів із низькою декоративністю в дослідженій дендрофлорі не виявлено. Отримані результати оцінки декоративності дендросозоекзотів $е x$ situ природно-заповідного фонду Степу України підтверджують думку про необхідність їх ширшого використання в садово-парковому будівництві.

\section{Джерела та література}

1. Абдуллина Р. Г. Методика оценки декоративности видов и сортов рода Sorbus L. / Р. Г. Абдуллина, Н. А. Рязанова // Известия Самарского научного центра. - 2015. - Т. 17, № 4. - С. $240-244$.

2. Аткина Л. И. Сезонная изменчивость колорита парковых пейзажей на примере насаждений дендропарка г. Екатеринбург / Л. И. Аткина, С. Н. Луганская, Т. А. Волкова // Вестник Башкирского государственного аграрного университета. - 2013. - № 3 (27). - С. 117-118.

3. Бабич Н. А. Интродуценты в зеленом строительстве северных городов : монография / Н. А. Бабич, О. С. Залывская, Г. И. Травникова. - Архангельск : Архан. гос. техн. ун-т, 2008. - 144 с.

4. Былов В. Н. Основы сравнительной сортооценки декоративных растений / В. Н. Былов // Интродукция и селекция цветочно-декоративных растений. - М. : Наука, 1978. - С. 7-31.

5. Власенко А. С. Аналіз видового складу дендросозоекзотів заповідних парків Степу України / А. С. Власенко // Наукові доповіді НУБіП України : електронний наук. фах. журн. - № 6 (48) [Електронний ресурс]. Режим доступу : http://nd.nubip.edu.ua/2014_6/19.pdf

6. Власенко А. С. Біоморфологічна та екологічна структура екзотичної дендросозофлори заповідних парків Степу України / А. С. Власенко // Автохтонні та інтродуковані рослини. - 2014. - Вип. 10. - С. 53-60.

7. Жиленко В. Ю. Разработка модифицированной шкалы оценки декоративности на примере некоторых представителей рода Berberis L. в условиях Белгородской области / В. Ю. Жиленко, В. Н. Сорокопудов, О. А. Сорокопудова // Вестник Новосибирского государственного аграрного университета. 2013. - № 2 (27). - C. 19-23.

8. Залывская О. С. Шкала комплексной оценки декоративности деревьев и кустарников в городских условиях на Севере / О. С. Залывская, Н. А. Бабич // Вестник Поволжского государственного технологического университета. - 2012. - № 1. - С. 96-104.

9. Зыкова В. К. Комплексная сортооценка Syringa vulgaris L. / В. К. Зыкова // Сборник научных трудов Государственного Никитского ботанического сада. - 2014. - Т. 136. - С. 99-106.

10. Калініченко О. А. Декоративна дендрологія : навч. посіб. / О. А. Калініченко. - К. : Вища шк., 2003. $200 \mathrm{c}$.

11. Колесников А. И. Декоративная дендрология / А. И. Колесников. - М. : Лесн. пром-сть, 1974. - 704 с.

12. Коляда Н. А. Декоративность североамериканских растений семейства Fabaceae Juss. в фазе цветения и плодоношения / Н. А. Коляда // Сибирский вестник сельскохозяйственной науки. - 2013. - № 4. C. $26-30$.

13. Коляда Н. А. Декоративные особенности некоторых североамериканских экзотов в дендрарии Горнотаежной станции ДВО РАН / Н. А. Коляда // Животный и растительный мир Дальнего Востока. Серия : Экология и систематика животных. - Уссурийск : Изд-во УГПИ, 2003. - Вып. 7. - С. 41-44.

14. Коляда Н. А. К методике оценки декоративности некоторых видов кустарников дендрария Горнотаежной станции дальневосточного отделения РАН / Н. А. Коляда // Сибирский вестник сельскохозяйственной науки. - 2011. - № 9-10. - С. 57-65.

15. Коляда Н. А. К методике оценки декоративности плодов древесных лиственных растений в дендрарии ГВС ДВО РАН / Н. А. Коляда // Вестник Иркутской государственной сельскохозяйственной академии. 2011. - Т. 1, № 44. - С. 80-85.

16. Котелова Н. В. Оценка декоративности / Н. В. Котелова, Н. С. Гречко // Цветоводство. - 1969. - № 10. C. $11-12$.

17. Котелова Н. В. Оценка декоративности деревьев и кустарников по сезонам года / Н. В. Котелова, О. Н. Виноградова // Физиология и селекция растений и озеленение городов. - 1974. - Вып. 51. - С. 32-44.

18. Крекова Я. А. Оценка декоративных признаков у видов рода Picea Dieter. в Северном Казахстане / Я. А. Крекова, А. В. Данчева, С. В. Залесов // Современные проблемы науки и образования. - 2015. № 1 [Электронний pecypc]. - Режим доступа : www.science-education.ru/121-17204.

19. Ланшакова Т. Р. Оценка декоративности кленов в дендрарии в г. Бирске (Башкирское Предуралье) / Т. Р. Ланшакова, Н. А. Рязанова // Вестник Оренбургского государственного университета. - 2011. № 12 (131). - C. 104-405.

20. Миронова Г. О. Основные принципы эстетической оценки хвойных парковых культурфитоценозов / Г. О. Миронова, О. П. Чекалин // Проблемы дендрологии, цветоводства, плодоводства : материалы междунар. конф. (6-10 октяб. 1997 г., Ялта). - Ялта, 1997. - Ч. 1. - С. 123-126. 
21. Мисник Г. Е. До оцінки декоративності дерев та чагарників у фазах їх цвітіння та плодоношення / Г. Е. Мисник // Біологія і культура деревних та чагарникових рослин. - К. : Наук. думка, 1964. C. $100-101$.

22. Мурзабулатова Ф. К. О методике оценки декоративности гортензий (Hydrangea L.) / Ф. К. Мурзабулатова, Н. В. Полякова // Известия Самарского научного центра Российской академии наук. - 2014. Т. 16, № 1. - С. 266-270.

23. Насурдинова Р. А. Оценка декоративных качеств видов рода Clematis L. в культуре на Южном Урале / Р. А. Насурдинова, О. Ю. Жигунов // Известия Уфимского научного центра РАН. - 2014. - № 1. - С. 65-71.

24. Оксантюк В. М. Сезонна зміна декоративності представників роду Cotinus Mill. / В. М. Оксантюк, Л. А. Колдар // Інтродукція рослин. - 2014. - № 4. - С. 58-63.

25. Остапко В. М. Шкала оценки декоративности петрофитных видов флоры юго-востока Украины / В. М. Остапко, Н. Ю. Кунец // Інтродукція рослин. - 2009. - №1. - С. 18-22.

26. Панина Г. А. Экзоты в зелёном строительстве Оренбургской области / Г. А. Панина, В. Ф. Абаимов // Вестник Оренбургского государственного педагогического университета. Электронный научный журнал. - 2013. - № 2 (3). - С. 58-62.

27. Полякова Н. В. Оценка декоративности сирени (Syringa L.) / Н. В. Полякова, В. П. Путехин // Аграрная Россия. - 2013. - № 2. - С. 14-19.

28. Рязанова Н. А. Оценка декоративности кленов в Уфимском ботаническом саду / Н. А. Рязанова, В. П. Путехин // Вестник Иркутской государственной сельскохозяйственной академии. - 2011. - Т. 4, № 44. C. $121-128$.

29. Сидоренко I. О. Методика оцінювання декоративності рослин видів роду Rhododendron L. / I. O. Сидоренко // Наукові доповіді Національного аграрного університету. - 2008. - № 3 (11). - С. 1-16.

30. Сидоренко I. О. Східно-азійські рододендрони та перспективи їх використання в урболандшафтах міста Києва : монографія. - К. : Аграр Медіа Груп, 2012. - 200 с.

31. Словарь ботанических терминов / под общ. ред. И. А. Дудки. - Киев : Наук. думка, 1984. - 308 с.

32. Слюсар С. І. Визначення сезонної декоративності видів родини Taxodiaceae, інтродукованих у Правобережний Лісостеп України / С. І. Слюсар // Інтродукція рослин. - 2002. - № 2. - С. 96-100.

33. Слюсар C. I. Інтродукція таксодієвих (Taxodiaceae F. W. Neger) в Лісостепу України / С. I. Слюсар, С. І. Кузнецов. - К. : НАУ, 2008. - 154 с.

34. Слюсар С. І. Визначення декоративності екземплярів виду Metasequoia glyptostroboides Hu et Cheng / С. І. Слюсар // Інтродукція рослин. - 2000. - № 1. - С. 96-98.

35. Ханина М. В. Разработка шкалы оценки декоративности деревьев и кустарников в зимний период / М. В. Ханина, А. И. Довганюк // Вестник ландшафтной архитектуры. - 2015. - № 5. - С. 95-99.

36. Хороших О. Г. Шкала комплексної оцінки декоративних ознак деревних рослин / О. Г. Хороших, О. В. Хороших // Науковий вісник Українського державного лісотехнічного університету. Дослідження, охорона та збагачення біорізноманіття. - 1999. - Вип. 9. 9. - С. 167-170.

Власенко Анастасия. Оценка декоративности дендросозофитов ex situ Степи Украины. Проанализированы современные методики оценки декоративности древесных растений, на основе чего разработана оригинальная шкала комплексной оценки декоративности раритетных видов древесных экзотических растений по основным морфологическим признакам. Разработанная шкала оптимизирована для лиственных и хвойных зимнезеленых, а также для листопадных деревьев и кустарников. Полученная шкала оценки включает четыре блока: оценку общей декоративности растения, оценку декоративности корки, оценку декоративности листьев или хвои, а также генеративных органов растения. Методика апробирована на 30 видах дендросозоэкзотов, охраняемых ex situ на территориях природно-заповедного фонда Степи Украины. По результатам оценки, три вида дендросозоэкзотов отнесены к группе наиболее декоративных (Malus niedzwetzkyana Dieck ex Koehne, Cercis chinensis Bunge и Liquidambar styraciflua L.), 23 - к группе высокодекоративных и четыре - к группе среднедекоративных видов. Полученные результаты оценки декоративности дендросозоэкзотов ex situ природно-заповедного фонда Степи Украины подтверждают мнение о необходимости их широкого использования в садово-парковом строительстве.

Ключевые слова: оценка декоративности, дендросозоэкзоты, ex situ, Степь Украины.

Vlasenko Anastasia. Evaluation of Decorativeness of Rare Arboreal plants Ex Situ of the Steppe of Ukraine. The modern methodologies for assessing decorativeness of woody plants were analyzed. On this basis the original integrated scale of decorativeness assessment of rare arboreal exotic plant species by the main morphological features was constructed. This scale was optimized for leaf-losing and evergreen coniferous, as well as deciduous trees and shrubs. The resulting rating scale comprises four blocks: assessment of the general decorativeness of plants, evaluation of decorativeness of bark, assessment of decorativeness of leaves or needles, as well as the generative organs of the plant. This method was tested on 30 species of rare arboreal plants, which are protected ex situ on the territories of Nature Reserve Fund of the Steppe of Ukraine. According to the evaluation, three species of rare arboreal plants were categorized as most decorative (Malus 
niedzwetzkyana Dieck ex Koehne, Cercis chinensis Bunge and Liquidambar styraciflua L.), 23 species - as highly decorative species and four - as species of middling decorativeness. The results of decorativeness evaluation of rare arboreal plants $e x$ situ of Nature Reserve Fund of the Steppe of Ukraine are support the view of the necessity of their widespread use in landscape gardening.

Key words: assessment of decorativeness, rare arboreal plants, ex situ, Steppe of Ukraine.

Стаття надійшла до редколегії 09.03.2016 p.

УДК 581.1:58.02

\section{Лариса Сергєєва, Лариса Броннікова}

\section{Стійкість до модельованого водного стресу R2 рослин тютюну, отриманих у результаті клітинної селекції з іонами важких металів}

Методом клітинної селекції із використанням катіонів $\mathrm{Cd}^{2+}$ отримано клітинні лінії й рослини R0, R1, R2 тютюну. Усі рослинні форми відзначалися стійкістю до летальних водних стресів. Стійкість варіантів була координована 3 підвищеним рівнем вільного проліну, який змінювався залежно від величини стресового тиску. Осмостійкість варіантів $є$ генетично обумовленою ознакою.

Ключові слова: тютюн, клітинна селекція, катіони кадмію, водний дефіцит, стійкість, пролін.

Постановка наукової проблеми та їі значення. Суттєва глобальна зміна клімату починає створювати помітний стресовий тиск на природні біосистеми та культивовані види навіть у тих регіонах, котрі раніше були придатними для росту та розвитку рослин. Отже зростає потреба в рослинних формах із підвищеним рівнем стійкості. 3 огляду на це дослідження різних аспектів стійкості до абіотичних стресів стає першочерговим у низці наукових проблем. При цьому виділяються окремі напрями: біологічні, екологічні, гуманітарні. Однак, оскільки наявні підходи не завжди відповідають рівню поставленого завдання, то виникає необхідність у висуненні нових ідей. Їх перспективність обумовлюватиметься низкою умов, а саме: універсальністю, екологічною безпекою, технологічністю, можливістю модифікацій. Їм відповідає клітинна селекція.

Аналіз досліджень із цієї проблеми. Клітинну селекцію багато років застосовують для виділення рослинних форм із покращеними властивостями [1-3]. Однак, як будь-який метод, вона потребує постійного вдосконалення. Тому нами було висунуто ідею застосування летальних доз іонів важких металів (IBM, НMI) у клітинній селекції для отримання генетично змінених форм рослин.

IBM відносять до категорії стресових чинників, котрі викликають різноманітні ураження організму. При цьому вони діють малими, а нерідко навіть залишковими кількостями. Це стосується фізіологічно неактуальних іонів $\mathrm{Hg}^{2+}, \mathrm{Pb}^{2+}, \mathrm{Ba}^{2+} \mathrm{Cd}^{2+}$. [4]. Відомо, що іони кадмію можуть чинити широкий шкодочинний вплив на рослини [5]. Цікавим $€$ факт, що іони $\mathrm{Cd}^{2+}$ можуть аналогічно діяти як на інтактні рослини, так і на клітинні культури $[6,7]$.

Катіони $\mathrm{Cd}^{2+}$ негативно впливають на окремі компартменти рослин ${ }^{+}$[7], особливо на дегідрини [8]. Дегідрини відносяться до білків пізнього ембріогенезу, LEA (late embryogenesis abundant proteins) $[9,10]$. Повністю функції LEA не встановлені, але вважається, що, накопичуючись при зневодненні, вони попереджують денатурацію макромолекул. Тобто простежуємо координацію механізмів у нормально функціонуючого організму.

Отже, маючи на увазі вказані властивості іонів $\mathrm{Cd}^{2+}$, ми використали їх при відборі рослинних форм із підвищеним рівнем стійкості до водного стресу.

На селективних середовищах, котрі містили летальні для клітинних культур дози катіонів $\mathrm{Cd}^{2+}$, виділено стійкі клітинні лінії. Різнопланове тестування за дії / зміни різних умов культивування підтвердило висунуту гіпотезу, а саме: клітинні лінії відрізнялися стійкістю не лише до IBM, але й до

(С Сергєєва Л., Броннікова Л., 2016 